\title{
Genetic diversity of Ehrlichia canis strains from naturally infected dogs in Rio de Janeiro, Brazil
}

\author{
Diversidade genética de cepas de Ehrlichia canis encontradas em cães naturalmente \\ infectados no Rio de Janeiro, Brasil
}
Renata Fernandes Ferreira ${ }^{1}$; Aloysio de Mello Figueiredo Cerqueira²; Tatiana Xavier de Castro²; Eliane de Oliveira Ferreira ${ }^{3,4}$; Felipe Piedade Gonçalves Neves²; André Victor Barbosa²; Daniel de Barros Macieira ${ }^{1}$; Nádia Regina Pereira Almosny ${ }^{1 *}$

\begin{abstract}
${ }^{1}$ Departamento de Patologia e Clínica Veterinária, Faculdade de Veterinária, Universidade Federal Fluminense - UFF, Niterói, RJ, Brasil

${ }^{2}$ Departamento de Microbiologia e Parasitologia, Instituto Biomédico, Universidade Federal Fluminense - UFF, Niterói, RJ, Brasil

${ }^{3}$ Departamento de Microbiologia Médica, Instituto de Microbiologia Paulo de Góes, Universidade Federal do Rio de Janeiro - UFRJ, Rio de Janeiro, RJ, Brasil

${ }^{4}$ Polo Xerém, Universidade Federal do Rio de Janeiro - UFRJ, Duque de Caxias, RJ, Brasil
\end{abstract}

Received February 21, 2014

Accepted June 25, 2014

\begin{abstract}
The aim of this study was to characterize Ehrlichia canis strains from naturally infected dogs in Rio de Janeiro, Brazil. In addition, all the clinical and hematological findings observed in these dogs were reported. PCR targeting the $16 \mathrm{~S}$ rRNA gene was used for diagnostic purposes, and the TRP19 and TRP36 genes were sequenced to evaluate the genetic diversity. Fifteen samples were positive for $E$. canis. The polymerase chain reaction for the TRP19 gene resulted in 11 amplicons (11/15), which were cloned into the pGEM-T easy vector for sequencing. The complete sequence of TRP19 gene was compared to those in the GenBank, revealing high identicalness. Phylogenetic analysis on the TRP36 gene sequences demonstrated two distinct strains from two dogs, named 56C and 70C. The 56C strain was grouped with the strain Cuiaba 16, which is a hybrid strain formed by Brazilian and US genogroups; and the 70C strain was grouped with other strains of the US genogroup, thus suggesting that there are at least two genogroups of E. canis in Rio de Janeiro (US and Brazilian). Those animals, in which the 70C and 56C strains were isolated, showed distinct clinical and hematological manifestations of ${ }^{1}$ the disease. The appearance of different genotypes may express new phenotypes, thus resulting in different forms of presentation of the disease and making its diagnosis more complex.
\end{abstract}

Keywords: Dogs, genogroups, TRP19, TRP36, CME.

\section{Resumo}

O objetivo deste estudo foi caracterizar as cepas de Ehrlichia canis em cães naturalmente infectados no Rio de Janeiro, Brasil. Além disso, os achados clínicos e hematológicos observados nos cães foram relatados. O gene 16S rRNA foi utilizado como alvo da PCR para fins diagnósticos, e os genes TRP19 e TRP36 para avaliar a diversidade genética. Quinze amostras foram positivas para E. canis. PCR para o gene TRP19 produziu 11 amplicons (11/15) que foram clonados no pGEM-T easy vector para sequenciamento. A comparaçáo das sequências completas do gene TRP19 com outras sequências depositadas no GenBank revelou uma alta identidade. Duas amostras (56C e 70C) após o ensaio da PCR, tendo como alvo o gene TRP36, geraram sequências, e a análise filogenética mostrou que a cepa 56C foi agrupada com a cepa Cuiabá 16, que é uma cepa híbrida, formada pelo genogrupo Brasileiro e o genogrupo US; e a cepa 70C agrupou com as outras cepas do genogrupo US, sugerindo a existência de pelo menos dois genogrupos de E. canis no Rio de Janeiro (US e Brasileiro). Esses animais apresentaram manifestaçôes clínicas e hematológicas distintas, e diferentes genótipos podem expressar novos fenótipos, resultando em diferentes formas de apresentação da doença e fazendo com que o diagnóstico seja mais complexo.

Palavras-chave: Cães, genogrupos, TRP19, TRP36, EMC.

\footnotetext{
${ }^{*}$ Corresponding author: Nádia Regina Pereira Almosny

Departamento de Patologia e Clínica Veterinária, Faculdade de Veterinária,

Universidade Federal Fluminense - UFF, Rua Vital Brazil Filho, 64, Santa

Rosa, CEP 24230-340, Niterói, RJ, Brasil

e-mail: almosny@vm.uff.br
} 


\section{Introduction}

Ehrlichia spp. is an $\alpha$-proteobacterium belonging to the order Rickettsiales that causes diseases of veterinary importance and is also responsible for emerging life-threatening anthropozoonoses. E. canis is a small Gram-negative, obligate intracellular dimorphic bacterium transmitted by the brown dog tick, Rhipicephalus sanguineus (RISTIC; HUXSOLL, 1984).

The glycoproteins TRP36 and TRP19 are species-specific major immune reactive proteins and appear to be important targets for the host immune response, attachment to the host cell and other potentially significant roles in the pathobiology of Ehrlichia. The genes encoding the TRP36 protein ( $-840 \mathrm{bp}$ ) and TRP19 protein ( $414 \mathrm{bp}$ ) have frequently been studied and have been used to identify different variations within the E. canis species (CARDÉNAS et al., 2007). The TRP19 gene is highly conserved, and thus has great potential for development of vaccines and sensitive serological tests when correlated with this protein (DOYLE et al., 2006). The TRP19 protein has been correlated with the acute (or early) immune response in dogs (McBRIDE et al., 2003) and presents reactivity that is also demonstrated in GP200, another immunoreactive protein present in E. canis (CARDÉNAS et al., 2007).

The TRP36 antigen is an acute-phase glycoprotein that is exposed on the bacterial surface and is secreted into the host cytoplasm (McBRIDE et al., 2003). It is an orthologue of the protein TRP47 of E. chaffeensis and has been used to differentiate between the variations that exist in the specie E. canis (DOYLE et al., 2005). Differences in the TRP36 gene have been reported, thus indicating some degree of $E$. canis diversity in nature, and studies have suggested that TRP36 is useful for genotyping $E$. canis strains based on differences in tandem repeat number or sequences (HSIEH et al., 2010; KAMANI et al., 2013).

In Brazil, the gene encoding the protein TRP36 has been used for bacterial typing, and new genogroups have emerged along with evidence of genetic recombination between different strains of $E$. canis (AGUIAR et al., 2013).

The aim of this study was to characterize $E$. canis strains from naturally infected dogs in Rio de Janeiro, Brazil, using a polymerase chain reaction (PCR) to target the TRP19 and TRP36 genes, and after sequencing, to perform bacterial typing. In addition, the clinical and hematological findings observed in dogs infected with $E$. canis strains from this study were reported.

\section{Materials and Methods}

\section{Blood collection}

A total of 300 blood specimens from client-owned dogs (146 male and 154 female) were obtained from veterinary clinics and home visits. These specimens were obtained from rural areas (100 each from the municipalities of Cachoeiras de Macacu and Maricá) and urban areas (100 from the municipality of Duque de Caxias) in the state of Rio de Janeiro (Figure 1) and were named according to the identification number of the animal followed by the initial letter of the municipality where it was collected ( $\mathrm{C}=$ Duque de Caxias; $\mathrm{M}$ = Maricá; $\mathrm{CM}$ = Cachoeiras de Macacu).

All the dogs were recruited at private veterinary clinics. Animals previously subjected to antibiotic therapy during the past four weeks were excluded from this study. Most samples (245/300; $81.1 \%$ ) were from dogs more than one year old. The population

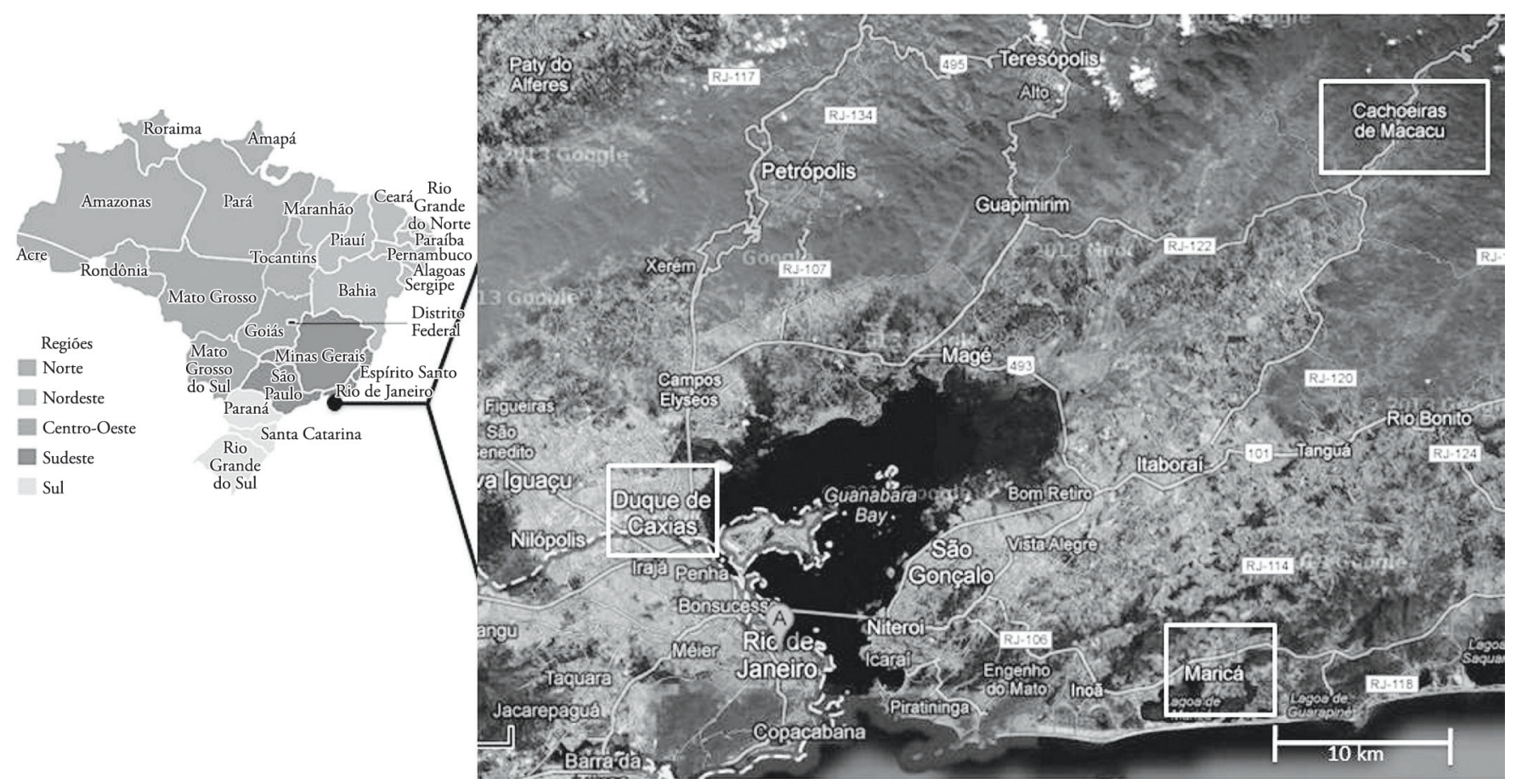

Figure 1. Map showing the regions of the state of Rio de Janeiro where the dogs of the present study were sampled. The squares indicate: Cachoeiras de Macacu, Duque de Caxias and Maricá, and highland and metropolitan regions, respectively. 
tested consisted of mixed-breed dogs (128/300; 42.7\%) and purebred dogs $(180 / 300 ; 60 \%)$.

The physical examination consisted of assessment of temperature, mucous appearance, presence of ticks, hepatomegaly and/or splenomegaly. The result from the physical examination was registered in a medical record, as well as any clinical signs reported by the owner. This trial was licensed by our institution's Ethics Committee for Animal Research (PROPPi/UFF - CEPA/NAL) under registration number 0087/2011, and dogs were included in the study only after written consent had been received from their owners.

\section{Collection and processing of blood samples, microscopic examination and DNA extraction}

All blood samples were collected from each dog before any treatment was started, by means of venipuncture using either the cephalic or the jugular vein. After collection, the samples were stored in commercial sterilized tubes with anticoagulant (EDTA, ethylenediaminetetraacetic acid) for hematological analysis and were kept at $-20{ }^{\circ} \mathrm{C}$ until extraction and use in PCR reactions.

Diff-quick blood smears were examined under an optical microscope (E-200 Nikon ${ }^{\circledR}$ ) by observing 100 random microscopic fields (Magnification: 1000x) to check for the presence of E. canis morulae. A cell blood count (CBC) was performed by means of an automated cell counter (Coulter T900 ${ }^{\circledR}$ ), in accordance with the manufacturer's instructions. The reference values for blood counts used in this study were: hematocrit $37 \%$ to $55 \%$; overall leukocyte count $6,000 / \mu \mathrm{L}$ to $17,000 / \mu \mathrm{L}$; and platelet count $200,000 / \mu \mathrm{L}$ to 500,000/ $\mu \mathrm{L}$ (MEINKOTH; CLINKENBEARD, 2000).

\section{Total DNA extraction and polymerase chain reaction (PCR)}

DNA was extracted from blood samples in EDTA solution by using the Ilustra Blood Genomic Prep Mini Spin Kit (GE Healthcare, São Paulo, Brazil), in accordance with the manufacturer's instructions. After purification, the DNA was kept at $-20^{\circ} \mathrm{C}$, until use.

The samples were initially subjected to PCR using a single pair of primers for species of the family Anaplasmataceae (EHR16SD/ EHR16SR) that amplify a 345 bp fragment of the 16S rRNA gene. These primers amplify several species, including $E$. canis, E. chaffeensis, E. muris, E. ruminantium, Anaplasma phagocytophilum, A. platys, A. marginale, A. centrale, Wolbachia pipientis, Neorickettsia sennetsu, $N$. risticii and $N$. helminthoeca (INOKUMA et al., 2001).

Samples that were positive with the EHR16SD/ EHR16SR primer pair were then subjected to a second conventional PCR assay using the primers ECAN/HE3, which amplify a 389 bp fragment of the $16 \mathrm{~S}$ rRNA E canis gene (adapted from Murphy et al. (1998)). In all the reactions, a positive control of E. canis DNA isolated from a dog that had previously been infected was used (accession number: JX392985). Milli-Q ${ }^{\circledR}$ water was used as a negative control.

For TRP19 gene characterization, a pair of primers (EC19F/ EC19R) was used to amplify a 414 bp fragment (HSIEH et al.,
2010). Another pair of primers (TRP36F and TRP36R) was used to amplify the TRP36 gene (DOYLE et al., 2005), for amplification of the following three regions: region 1 (a N-terminal region with $429 \mathrm{bp}$ ); region 2 (a tandem repeat region with variable numbers of the 27 bp repeat unit, depending on the isolate); and region 3 (a C-terminal region with $87 \mathrm{bp}$ ). The DNA obtained from DH82 infected with $E$. canis (accession number: DQ146154) was used as a positive control. Milli-Q water was used as a negative control.

\section{Cloning and DNA sequencing analysis}

The amplicons obtained from PCR by using primers designed for the TRP19, TRP36 and 16S genes were column-purified using the Pure Link ${ }^{\circledR}$ Quick Gel extraction purification kit Invitrogen $^{\mathrm{TM}}$ ) and then the PCR-amplified fragments were cloned into the pGEM-T easy vector (Promega), in accordance with the manufacturer's instructions. The fragments were ligated into the p-GEM-T easy vector and transformed by means of electroporation into Escherichia coli $\mathrm{Bl} 21$ electrocompetent cells. The transconjugants were selected in LB agar containing X-Gal $(50 \mathrm{ug} / \mathrm{mL})$ and ampicillin $(100 \mathrm{ug} / \mathrm{mL})$ after incubation overnight at $37^{\circ} \mathrm{C}$. White colonies were chosen and grown in LB broth with $100 \mathrm{ug} / \mathrm{mL}$ ampicillin under agitation $(250 \mathrm{rpm})$ at $37^{\circ} \mathrm{C}$. The plasmid vector containing the insert was extracted using the alkaline lysis extraction method (EHRT; SCHNAPPINGER, 2003) and was sequenced with primer pairs targeting the TRP19 and TRP36 genes to confirm the cloned DNA fragment.

For the sequencing analysis, clones were purified using GFX PCR DNA and the Gel Band purification kit (GE Healthcare) and were subjected to direct sequencing using the BigDye terminator v. 1.1 cycle sequencing kit (Applied Biosystems, Los Angeles, CA, USA). Both strands of each amplicon were sequenced and the alignments were retrieved and analyzed by means of the Bio Edit sequence alignment editor v. 7.1.11 (http://mbio.ncsu.edu/BioEdit/ bioedit.html). The primers were removed and the sequences were compared with other genotypes of E. canis available at GenBank (www.ncbi.nlm.nih.gov/genbank). All sequences derived from the Brazilian E. canis genotypes generated in this study were deposited in GenBank

Nucleotide identicalness with the GenBank database was assessed using the BLAST tool (http://www.ncbi.nlm.nih.gov/ blast). A phylogenetic tree was constructed by means of the neighbor-joining method with 1,000 boot-strap replicates, within the MEGA 5.1 software program (Tamura et al., 2011), using three gene regions based on the divergent TRP36 N-terminal, tandem repeat region and C-terminal sequences (DOYLE et al., 2006)

\section{Detection of other vector-borne pathogens}

In order to investigate cases of coinfection with $A$. platys, the 15 samples that were positive for E. canis were subjected to another PCR reaction using the primer Ehr16SR/platys (INOKUMA et al., 2001). This did not show any amplification. Babesia sp. was also investigated in blood smears, but was not observed. 


\section{Results}

A total of $15 / 300$ samples (5.0\%) were positive for E. canis using the ECAN/HE3 primer pair. All the amplicons were subjected to sequence analysis. Partial sequencing of the $16 \mathrm{~S}$ rRNA gene was performed and the sequences from the present study shared higher nucleotide identicalness (97\% to 99\%) than did sequences from $E$. canis strains detected in different geographical areas worldwide. These sequences were deposited in the GenBank database (KJ995830, KJ995831, KJ995832, KJ995833, KJ995834, KJ995835, KJ995836, KJ995837, KJ995838, KJ995839, KJ995840, KJ995841, KJ995842, KJ995843, KJ995844).

Eleven of these 15 samples generated amplicons after PCR with the EC19F/EC19R primers and were then subjected to cloning and sequence analysis. For the other four samples, sequencing was not performed due to difficulties in recovering the genetic material or exhaustion of the sample. Comparison of the 11 complete TRP19 gene sequences of Brazilian E. canis obtained in this study with other strains previously deposited from Brazil and Taiwan in the GenBank database showed that the present samples had higher nucleotide identicalness. Despite the high similarity found, a silent mutation was observed at nucleotide 312 (Figure 2) in three samples: 39C (KF233417), 56C (KF233418) and 49CM (KF233425).

Two out of the 15 samples generated amplicons after PCR with the GP36F/GP36R primers and were subjected to cloning and sequence analysis: 56C (KF233413) and 70C (KF233414). For the other 13 samples, sequencing was not performed due to difficulties in recovering the genetic material or exhaustion of the sample.

Sequence analysis on a 429 bp fragment encoding the TRP36 protein (N-terminal region) revealed that the strain $70 \mathrm{C}$ shared the highest nucleotide identicalness with the isolates described in the US genogroup: São Paulo (DQ146154; 100\%); Presidente Prudente (JX312076; 99\%), Petrolina (JX312078; 99\%), Jake (DQ085427; 99\%), Florida (DQ146152; 99\%), Oklahoma (DQ085428; 99\%), Demon (DQ085429; 99\%), Louisiana (DQ146151; 99\%), North Carolina (DQ146153; 99\%) and Cameroon 71 (DQ146155; 100\%).
The sequence obtained from animal 56C shared high nucleotide identicalness with four other $E$. canis isolates described in the Brazilian genogroup: Cuiabá 1 (JX31207; 100\%); Belém (JX429924; 100\%); Londrina (JX312080; 100\%) and Monte Negro (15; 97\%).

The number of tandem repeat sequences (TEDSVSAPA) ranged from five copies (from animal 70C) to eight copies (from animal 56C). As a result, the entire gene encoding the protein TRP36 showed variations in the number of nucleotides, ranging from $662 \mathrm{bp}$ to $790 \mathrm{bp}$. The amino acid sequences of the related samples $56 \mathrm{C}$ and $70 \mathrm{C}$ of the TRP36 gene are described in Table 1.

Using all three regions of all Brazilian $E$. canis strains $(\mathrm{n}=8)$ that are available in the GenBank database and 11 others that have been reported worldwide, based on the divergent TRP36 $\mathrm{N}$-terminal, one tandem repeat region and C-terminal sequences, a phylogenetic tree was constructed (Figure 3). The phylogenetic analysis among the Brazilian and other worldwide E. canis strains was performed based on the model proposed by Aguiar et al. (2013).

The two strains (56C and 70C) isolated from Rio de Janeiro have the same tandem repeat sequence (TEDSVSAPA) and are grouped in a large clade called US genogroup (A1 and A2; Figure 3), diverging only in the number of tandem repeats (5-8). The 56C sample was segregated to a small branch (A2) consisting of a single hybridizing sample (Cuiabá 16; JX312077), possibly forming a new clade.

Regarding the presentation of the disease in these two animals, it was observed that the 56C strain was collected from a vaccinated and worm-treated nine-year-old male English Cocker Spaniel for which apathy was the main complaint. No fever or coagulation disturbances were reported. Other clinical signs, such as weight loss, pale mucous membranes, hepatomegaly and splenomegaly were also reported. The hematological findings were anemia $(12 \%$ hematocrit), thrombocytopenia $(37,000 / \mu \mathrm{L})$ and leukocytosis $(27,100 / \mu \mathrm{L})$. This animal had been acquired in the city and no travel history was reported.

On the other hand, the 70C strain was collected from a fourmonth-old female puppy of mixed breed that had completed the vaccination protocol, undergone worm treated and was tick-free, and which did not have any main complaint. Therefore, no clinical signs were observed and the dog presented only thrombocytopenia $(46,000 / \mu \mathrm{L})$. No travel history was reported.

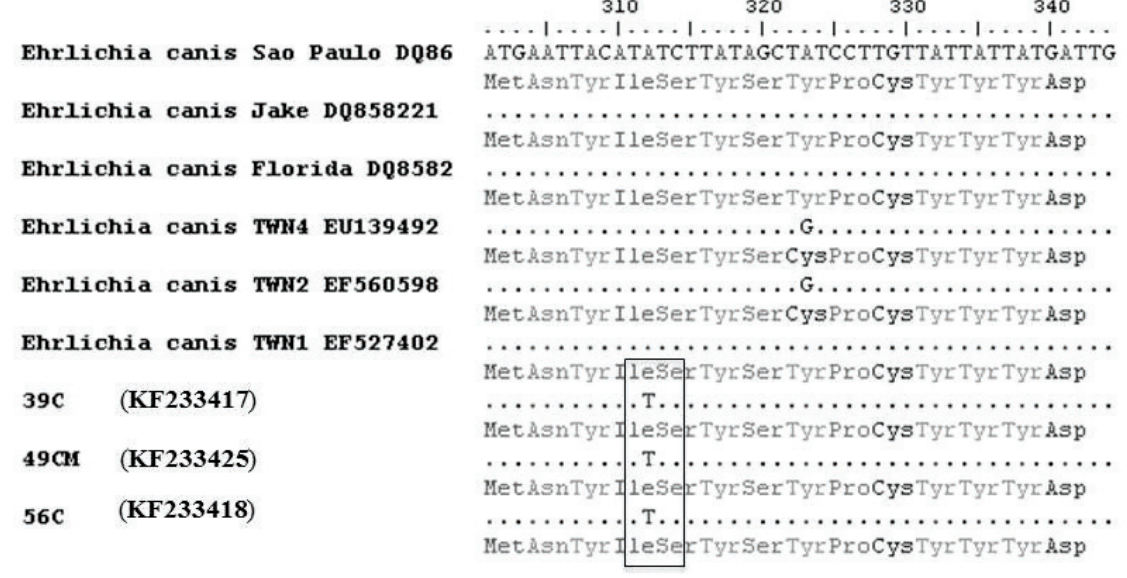

Figure 2. TRP19 amino acid sequences from Ehrlichia canis strains from Brazil and worldwide. The square shows a silent mutation in nucleotide 312 , where an adenine is replaced by a thymine. 


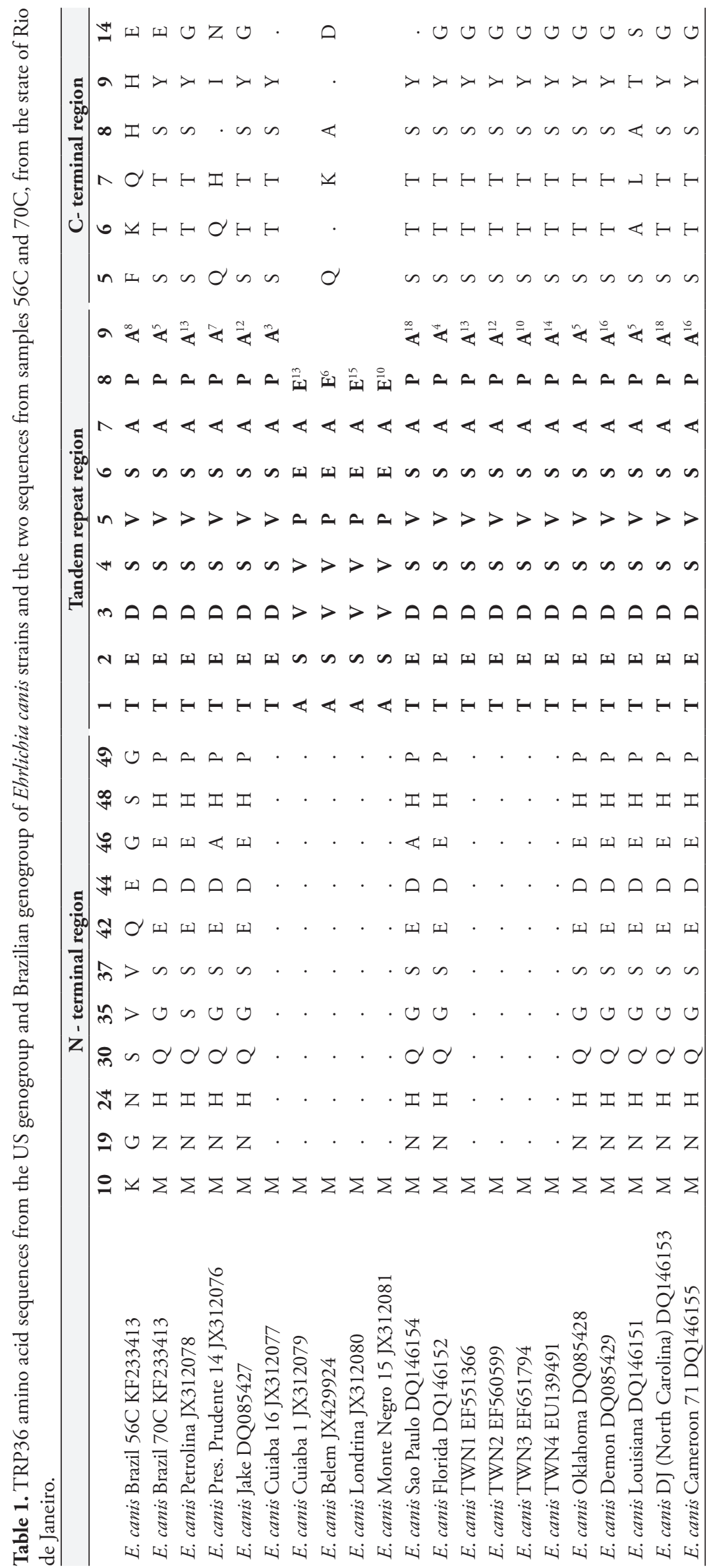




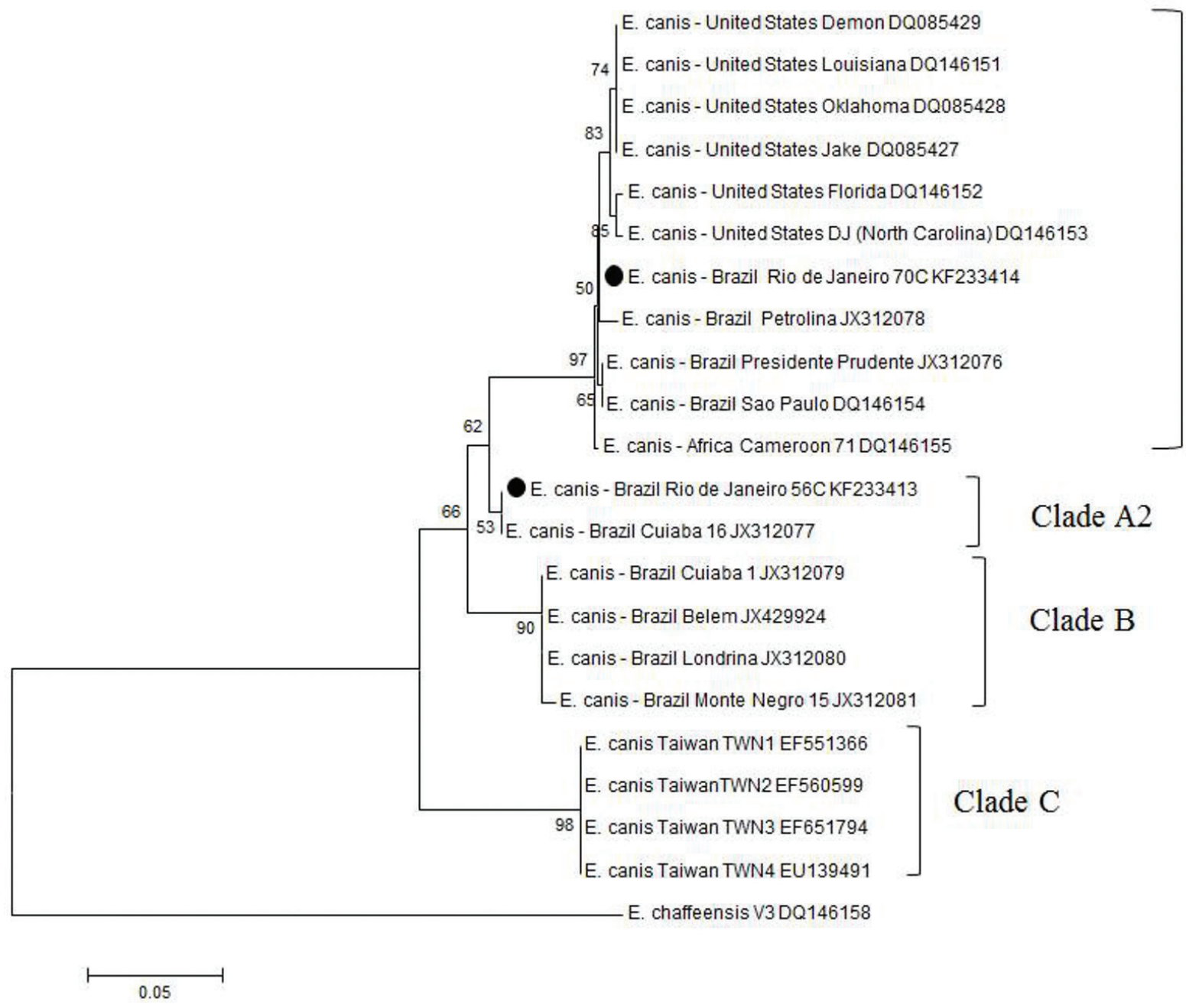

Clade A1

Figure 3. Phylogenetic tree based on the Ehrlichia canis TRP36 nucleotide sequences from Brazilian strains isolated in this study and other strains worldwide. The numbers at the nodes represent $50 \%$ of 1,000 bootstrap resamplings. Clades A1 and A2 represent the US genogroup, Clade B represents the Brazilian genogroup and Clade C represents the major group of E. canis genotypes. Clade A1 shows where the $70 \mathrm{C}$ strain is placed and clade A2 shows where the $56 \mathrm{C}$ strain is placed. The E. chaffeensis TRP47 gene sequence (TRP36 gene orthologue) was included as an outgroup.

\section{Discussion}

This study presented the first characterization of the TRP36 and TRP19 genes of E. canis from naturally infected dogs in Rio de Janeiro, Brazil and their correlation with the clinical and hematological descriptions shown by the diseased dogs. The results will contribute towards understanding some aspects of the E. canis disease and towards elucidating the diversity of $E$. canis strains, despite the limited number of animals in this study.

When the whole sequences of the gene encoding for the surface glycoprotein TRP19 of the 11 samples that were positive for $E$. canis by means of PCR were analyzed and compared with other sequences available in GenBank, a high degree of identicalness was observed. This result was expected, since the gene encoding the TRP19 protein is highly conserved. Doyle et al. (2006) proposed that the TRP19 protein could be a good candidate for creating a serological assay and could be used to develop a vaccine for ehrlichiosis. Even though a silent mutation in nucleotide 312 was detected, the sequences were still highly conserved, thus corroborating this hypothesis.

In Brazil, two genogroups based on the amino acid sequences of the tandem repeat region are circulating and they have different patterns: the Brazilian genogroup (ASVVPEAE) and the US genogroup (TEDSVSAPA). The Brazilian genogroup has only been described in the northern and southern regions, while the US genogroup has described in the northeastern and southeastern regions. In the central-western region, a hybrid (Cuiabá 16) has been described, possibly created through an association between two strains of different genogroups. The Brazilian genogroup has not been described in the southeastern region (AGUIAR et al., 2013). Since the sequence $56 \mathrm{C}$ was grouped with the sequence Cuiabá 16 and the identicalness between the sequences of the $\mathrm{N}$-terminal region was high (100\%), these sequences formed a new branch in the US genogroup, thus confirming that in the 
state of Rio de Janeiro, the Brazilian genogroup may also be circulating, since the Cuiabá 16 nucleotide sequence and the 56C nucleotide sequence showed 100\% identicalness with the $\mathrm{N}$-terminal regions of sequences from the Brazilian genogroup (Cuiabá 1, Belém and Londrina). On the other hand, the animal infected with this strain (56C) did not have any history of travel to any of the regions where the Brazilian genogroup had already been described, which reinforces the idea suggested by Aguiar et al. (2013) that recombination between strains of $E$. canis exists in Brazil, where the prevalence is high.

Regarding the region of tandem repeat sequences of the samples described (56C and 70C), the number of tandem repeats (tedsvsapa) ranged from five copies (70C) to eight copies (56C). As a consequence of this variation, the whole gene that encodes the TRP36 protein presented variation in the numbers of nucleotides and amino acids (CARDÉNAS et al., 2007). One important issue that should be pointed out is the fact that the number of tandem repeats can result in different conformations of the protein, thereby changing its biological function and behavior (ALBERTS et al., 2008).

By combining the clinical and hematological findings presented by the animals with the results from the analyses on the sequences obtained from the samples 56C and 70C, some interesting differences were observed. The animal $70 \mathrm{C}$ was infected with a strain that belongs to the US genogroup, which is the oldest genogroup described and the one that is most prevalent on Brazilian territory, and this animal did not show any clinical signs of disease. Regarding hematological changes, only thrombocytopenia $(46,000 / \mu \mathrm{L})$ was observed. When treatment is not administered and the animal is immunodeficient (as in the case of the animal 70C), Canine Monocytic Ehrlichiosis has three phases: acute, subclinical and chronic (WOODY; HOSKINS, 1991). Although this puppy was immunodeficient and a severe acute phase was expected, a subclinical phase was observed.

In general, puppies present the classic form of the disease due to deficiency in their immune response. This implies the onset of clinical signs and hematological findings such as apathy, weight loss, fever, hepatomegaly, splenomegaly, anemia, leukopenia or leukocytosis (WOODY; HOSKINS, 1991, NEER 1998; VIEIRA et al., 2011). This did not happen in this case, given that this animal was brought back to the clinic for reinforcement every 21 days after the first vaccine dose (at the age of 45 days). It could happen due to factors relating to the host's adaptation to bacteria, since the US genogroup seems to be the oldest type (AGUIAR et al., 2013).

The animal 56C, which was infected with a hybrid sample, showed the acute classic form of the disease, as expected, showing clinical signs such as weight loss, pale mucous membranes, splenomegaly and hepatomegaly. The hematological findings were severe anemia (hematocrit $12 \%$ ), thrombocytopenia $(37,000 / \mu \mathrm{L})$ and leukocytosis $(27,100 / \mu \mathrm{L})$, thus suggesting that these were a means of adaptation by the bacteria, as a response to selective pressure experienced, since TRP genes have been associated with functional host-pathogen interactions such as adhesion, internalization, actin nucleation and immune evasion (McBRIDE; WALKER, 2011).
Although no coinfections with $A$. platys and Babesia sp. were detected in samples that tested positive for E. canis in this study, other vector-borne pathogens associated with hematological changes in dogs, such as Leishmania sp. and Leptospira sp., should be included in the differential diagnosis in cases of dogs with hematological disorders (VIEIRA et al., 2011).

\section{Conclusion}

The present study was the first attempt to evaluate the genetic diversity of E. canis using TRP19 and TRP36 gene targets, in Rio de Janeiro, Brazil. Despite the limited number of samples, we can suggest that at least two distinct genogroups were present. Coexistence of different genogroups needs to be carefully monitored, since this gives rise to diversity in the genes encoding proteins, which is directly related to the host immune response. Different genotypes may express new phenotypes, thereby resulting in different forms of disease presentation.

\section{Acknowledgements}

The authors are grateful to Dr. Miguel Angelo da Silva Medeiros for providing the Ehrlichia canis positive control and to CAPES, $\mathrm{CNPq}$ and FAPERJ for the financial support.

\section{References}

Aguiar DM, Zhang X, Melo AL, Pacheco TA, Meneses AM, Zanutto MS, et al. Genetic diversity of Ehrlichia canis in Brazil. Vet Microbiol 2013; 164(3-4):315-321. PMid:23490559. http://dx.doi.org/10.1016/j. vetmic.2013.02.015

Alberts B, Johnson A, Lewis J, Raff M, Roberts K, Walter P. How cells read the genome: from DNA to protein. In: Alberts B, Johnson A, Lewis J, Raff M, Roberts K, Walter P. Molecular biology of the cell. New York: Garland Science; 2008. p. 329-410.

Cardénas AM, Doyle CK, Zhang X, Nethery K, Corstvet RE, Walker $\mathrm{DH}$, et al. Enzyme-linked immunosorbent assay with conserved immunoreactive glycoproteins gp36 and gp19 has enhanced sensitivity and provides species-specific immunodiagnosis of Ehrlichia canis infection. Clin Vaccine Immunol 2007; 14(2): 123-128. PMid:17151186 PMCid:PMC1797795. http://dx.doi.org/10.1128/CVI.00361-06

Doyle CK, Cardenas AM, Aguiar DM, Labruna MB, Ndip LM, Yu XJ, et al. Molecular characterization of E. canis gp36 and E. chaffeensis gp47 Tandem Repeats among isolates from different geographic locations. Ann NY Acad Sci 2005; 1063: 433-435. PMid:16481555. http://dx.doi. org/10.1196/annals.1355.079

Doyle CK, Nethery KA, Popov VL, McBride JW. Differentially expressed and secreted major immunoreactive protein orthologs of Ehrlichia canis and Ehrlichia chaffeensis elicit early antibody responses to epitopes on glycosylated tandem repeats. Infect Immun 2006; 74(1): 711-720. PMid:16369028 PMCid:PMC1346619. http://dx.doi.org/10.1128/ IAI.74.1.711-720.2006

Ehrt S, Schnappinger D. Isolation of Plasmids from E. coli by Alkaline Lysis. Methods Mol Biol 2003; 235: 75-78. PMid:12904648.

Hsieh Y, Lee CC, Tsang CL, Chung YT. Detection and characterization of four novel genotypes of Ehrlichia canis from dogs. Vet Microbiol 
2010; 146(1-2): 70-75. PMid:20451333. http://dx.doi.org/10.1016/j. vetmic.2010.04.013

Inokuma H, Brouqui P, Drancourt M, Raoult D. Citrate synthase gene sequence: a new tool for phylogenetic analysis and identification of Ehrlichia. J Clin Microbiol 2001; 39(9): 3031-3039. PMid:11526124 PMCid:PMC88292. http://dx.doi.org/10.1128/JCM.39.9.30313039.2001

Kamani J, Baneth G, Mumcuoglu KY, Waziri NE, Eyal O, Guthmann Y, et al. Molecular Detection and Characterization of Tick-borne Pathogens in Dogs and Ticks from Nigeria. PLoS Negl Trop Dis 2013; 7(3): e2108. PMid:23505591 PMCid:PMC3591325. http://dx.doi. org/10.1371/journal.pntd.0002108

McBride JW, Corstvet RE, Gaunt SD, Boundreaux G, Guedry T, Walker DH. Kinetics and antibody response to Ehrlichia canis immunoreactive proteins. Infect Immun 2003; 71(5): 2516-2524. PMid:12704123 PMCid:PMC153292. http://dx.doi.org/10.1128/LAI.71.5.2516-2524.2003

McBride JW, Walker DH. Molecular and cellular pathobiology of Ehrlichia infection: targets for new therapeutics and immunomodulation strategies. Expert Rev Mol Med 2011; 13: e3. PMid:21276277 PMCid:PMC3767467. http://dx.doi.org/10.1017/S1462399410001730

Meinkoth JH, Clinkenbeard KD. Normal hematology of the dog. In: Feldman BF, Zinkl JG, Jain NC. Schalm's Veterinary Hematology. 5th ed. Baltimore: Lippincott Williams e Wilkins; 2000. p. 1057-1063.
Murphy GL, Ewing SA, Whitworth LC, Fox JC, Kocan AA. A molecular and serologic survey of Ehrlichia canis, Ehrlichia chaffeensis and E. ewingii in dogs and ticks from Oklahoma. Vet Parasitol 1998; 79(4): 325-339. http://dx.doi.org/10.1016/S0304-4017(98)00179-4

Ristic M, Huxsoll DL. Tribe II Ehrlichieae. In: Holt, JG. Bergey's Manual of Systematic Bacteriology: Gram-negative bacteria of general, medical, or industrial importance. Baltimore: Williams \& Wilkins; 1984. p.704709. v. 1.

Tamura K, Peterson D, Peterson N, Stecher G, Nei M, Kumar S. MEGA 5: Molecular evolutionary genetics analysis using maximum likelihood, evolutionary distance, and maximum parsimony methods. Software Version 5.05. Mol Biol Evol 2011; 28(10): 2731-2739. PMid:21546353 PMCid:PMC3203626. http://dx.doi.org/10.1093/molbev/msr121

Neer, TM. Ehrlichiosis: canine monocytic and granulocytic ehrlichiosis. In: Greene CE. Infectious diseases of the dog and cat. 2nd ed. Philadelphia: WB Saunders Company; 1998. cap. 28, p. 139-154.

Vieira RFC, Biondo AW, Guimarães AM, Santos AP, Santos RP, Dutra LH, et al. Ehrlichiosis in Brazil. Rev Bras Parasitol Vet 2011; 20(1):1-12. PMid:21439224. http://dx.doi.org/10.1590/S198429612011000100002

Woody BJ, Hoskins JD. Ehrlichial diseases of dogs. Vet Clin North Am Small Anim Pract 1991; 21(1): 75-98. PMid:2014630. 